\title{
ANALYSIS OF THE ELECTORAL RESULTS FROM THE ROMANIAN LEGISLATIVE ELECTIONS IN 2020
}

DOI: https://doi.org/10.18509/GBP210195d

UDC: 324(498)"2020"

\author{
Andrei Ducman \\ Irina-Valentina Rădoi \\ Camelia Teodorescu \\ Vasile-Gabriel Dascălu \\ Karina-Andreea Gruia \\ University of Bucharest, Faculty of Geography, Department of Human and Economic \\ Geography; Bucharest, Romania CAIMT (Research Center for Integrated Analysis and \\ Territorial Management), University of Bucharest, Romania
}

\begin{abstract}
Electoral periods have always been a challenge for representative parties to gain new supporters, but also to get closer to the population, and the context of the Coronavirus pandemic has been a barrier to traditional election campaigns, requiring their relocation to the online environment. The main target of the online campaigns was the young population, while the street election campaigns wanted to convince the majority of the adult population, who do not spend much of their time in the online field. The central objective of the study was to identify voting trends at the national level, but also at the regional level. The secondary objective of the study was to identify the influence of national minorities in the Romanian legislative elections, based on a significant population of ethnic Hungarians in certain counties. The aim of the study was to provide a point of support for electoral statistics and to be translocated to cartographic materials, to facilitate their understanding. The results of the study certify that there is a regionalization of the electoral results, with small exceptions, and the party representing the ethnic Hungarians won detachedly in the counties where they are the majority.
\end{abstract}

Keywords: electoral geography, election campaign, online, political parties, social media

\section{INTRODUCTION}

Politics is an extremely important challenge since ancient times for people who are involved in the political act, but also for people who have the responsibility to choose the representatives of this political class, and will have extremely relevant implications from an economic and social point of view, politics is often characterized as a mirror of a society [1][2][3][5][6]. Due to the complexity of the political act, it often manages to remove the population from exercising the right to vote, the common mentality being directed towards an overwhelming distrust in what could change the voting results, but the representatives of political parties manage to create extremely complex plans to create possible political niches, based on an extremely well-analyzed national territorial reality [8]. The creation of political niches could not be achieved without knowing the territorial reality at local, regional and national level, through the complex and dynamic nature of the target population, election campaigns must be well managed and directed to increase the political potential in that area. Thus, the research wants to identify and analyze which are the dominant niches of the political parties that have managed to gain trust at the local 
level (by counties), but also at the regional level (in the social and cultural regions of Romania) [4][7][11]. Cultural diversity at the national level contributes to the differentiated development of the state, from an economic, social and cultural point of view, which introduces into discussion the need for a sectional analysis of the human component, especially in political processes [9][10][12]. Due to the fact that Romania represented a border point between the communist space and the western space, there are territorial differences in the political mentality of the people, observing a character of direction towards liberalism and central policies for the western population, a majority direction towards social democratic ideology in areas with a low economic and educational level, but also a gradual increase in the level of trust in the Social Democratic Party, which takes place on the west - east axis [13].

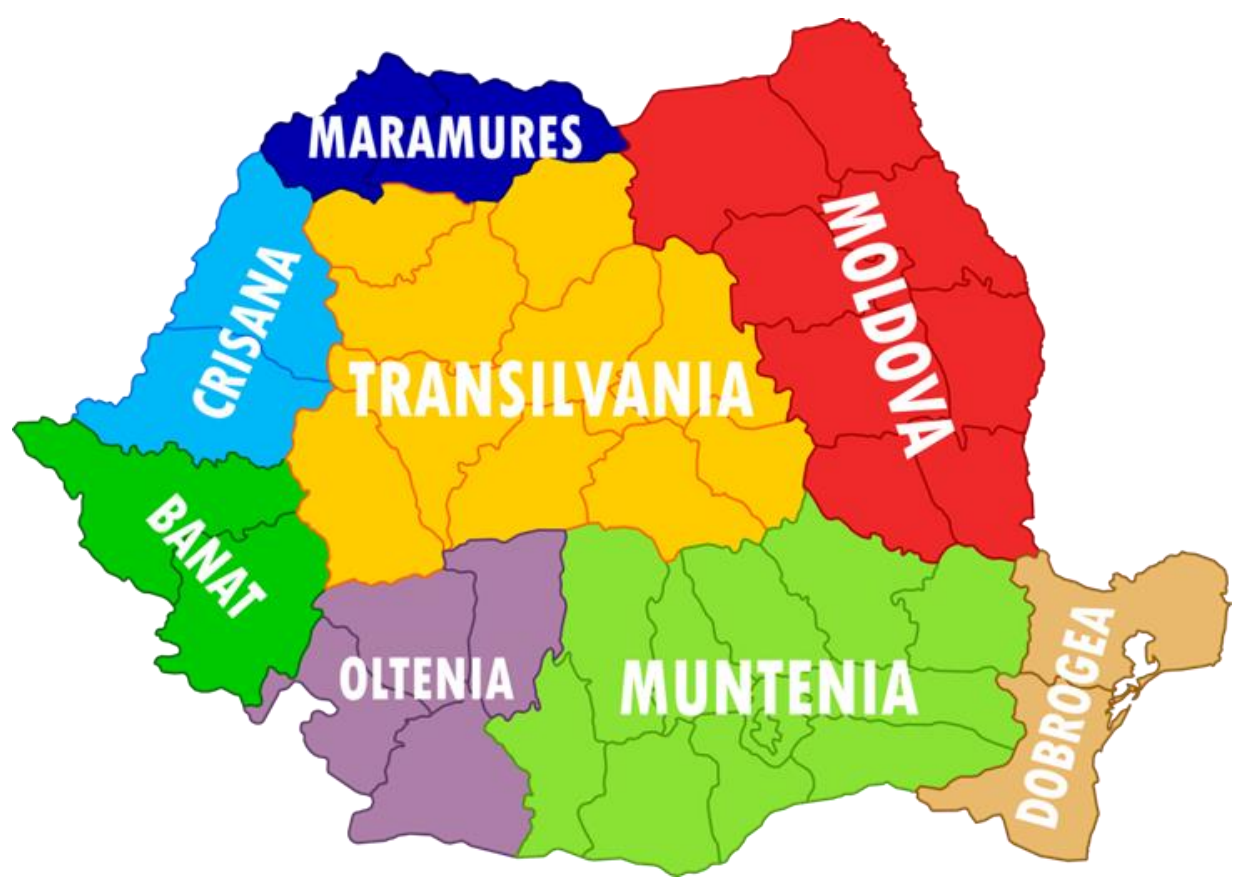

Figure 1. Regional map of Romania

\section{METHODOLOGY}

The research proposes to analyze the existing cultural and social differences on the territory of the state, these taking place on the basis of extremely complex factors, including proximity to different ideological areas, educational and economic level, but also the general mentality and attitude. of the population towards the political process. These cannot be analyzed without the existence of pre-existing regions, such as Romania, which has eight different regions, from a social and cultural point of view, namely Banat, Crișana, Dobrogea, Maramureș, Moldova, Muntenia, Oltenia and Transylvania (Figure 1). The research was developed based on data provided by the Central Electoral Bureau, the authority that administers citizens' votes and provides final results in the electoral process, provided in the form of data tables, transformed into cartographic materials (for each region) using inkScape 0.91 software.

\section{RESULTS AND DISCUSSIONS}

The Banat region is characterized by a trend of acceptance towards the liberal or central part of the political scene, through the residents' preferences towards the PNL and 
USRPlus parties, obtaining scores of over $29 \%$ in both component counties. Due to the high degree of development, from an economic and educational point of view, the Banat region proposes a promotion of free political principles at local and regional level. The aggressive political promotion carried out by the liberal parties in this region of the country is based on a historical foundation based on the desire for freedom, but also on removing the communist historical premises from regional and national level, this region being the beginning of the communism fall since 1989. (Figure 2).

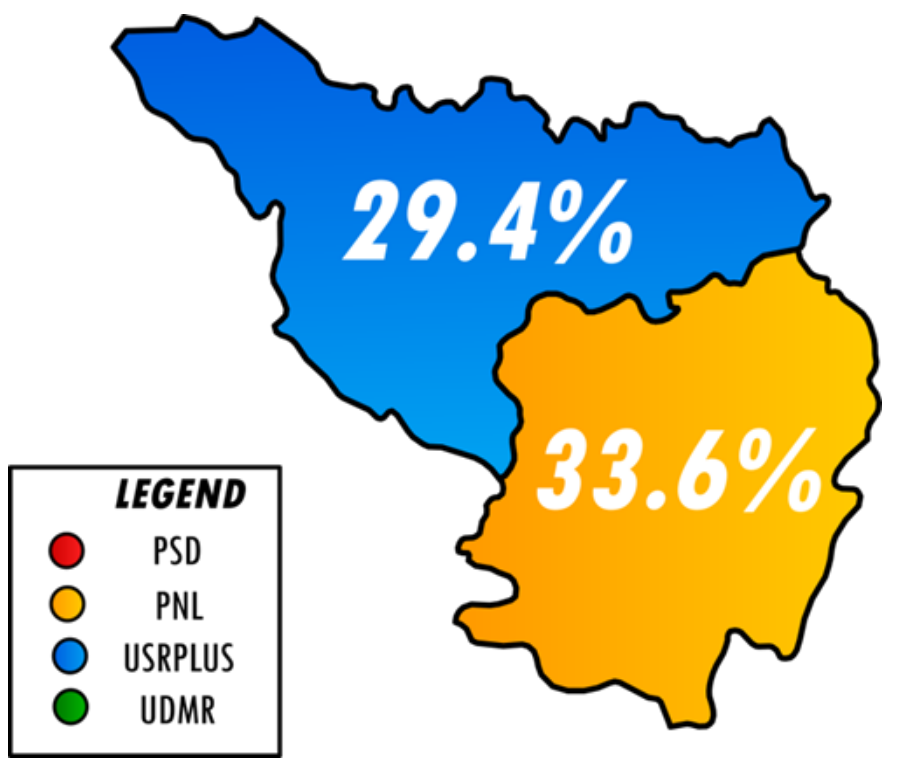

Figure 2. Electoral results of the legislative elections - Banat (2020)

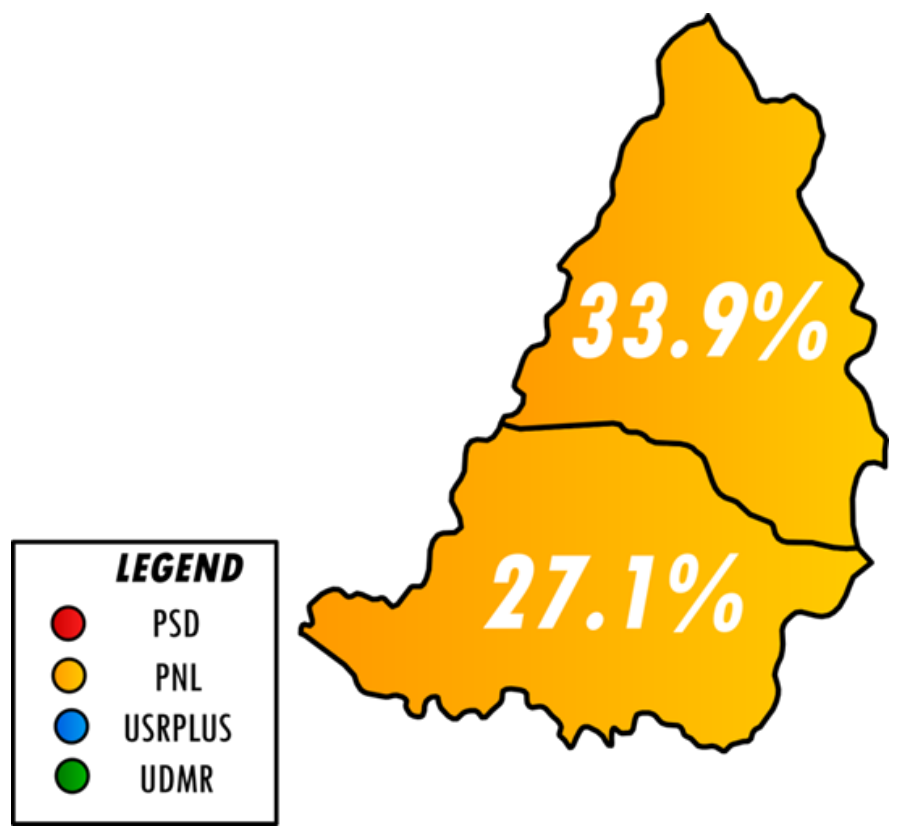

Figure 3. Electoral results of the legislative elections - Crișana (2020).

Together with the Banat region, the Crișana region manages to create a longitudinal strip of liberal and central influence in western Romania, based on a cultural rapprochement between the two regions of Romania, but also on an extremely beneficial collaboration in all possible sectors. History is also decisive in the case of this region, as the proximity to a non-communist area allowed exchanges of information, ideologies and cultural 
exchanges during the Romanian communist period, which facilitated the fixation of the concept of economic, social and cultural freedom in mentality. of residents in this region. Also, from a historical point of view, the area was an important point in the AustroHungarian Empire, which contributed to the creation of specific features that are visible today (Figure 3). All the regions (Banat, Crișana, Maramureș, Transylvania) that were components of this old empire are today poles of a liberal policy, in a process of interpenetration with the parties representative for the old Hungarian communities in the country (UDMR).

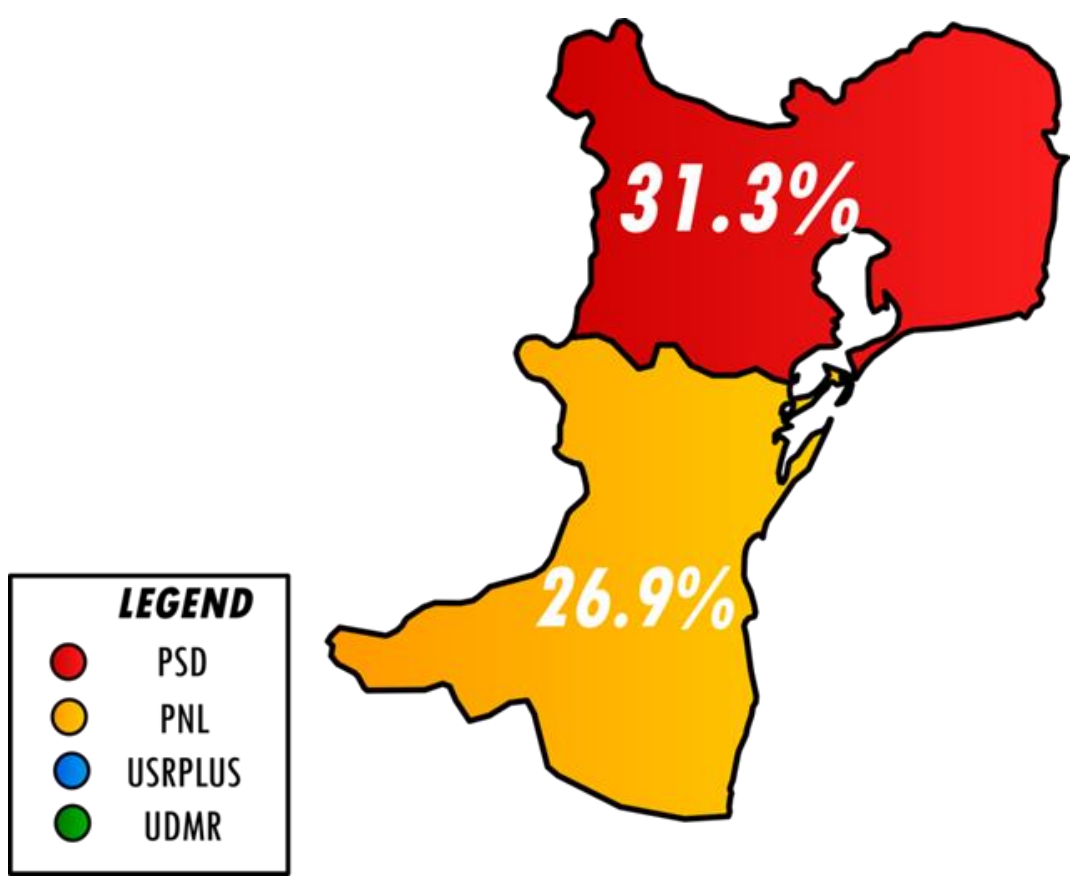

Figure 4. Electoral results of the legislative elections - Dobrogea (2020).

The Dobrogea region has always represented an extremely relevant space for the leaders of the political parties, by opening a multitude of development possibilities in the coastal area, especially in the naval area or in the port area of Constanta. The component counties are in a complete antithesis, through an increased restrictivity of the Tulcea area, and an extremely vast possibility of expansion for Constanta county, which led to a digression of political forces towards the second county, which has a mentality. more open to liberalism, opting for the main right-wing option, namely the National Liberal Party, in contrast to the option of Tulcea County to the Social-Democratic Party, illustrating the differences in mentality between the two administrative areas. (Figure 4)

The Maramuress region is a northern continuation of the liberal band in western Romania, continuing through Crișana and Banat, thus offering a western border with right-wing political ideology, with the exception of Satu Mare county, where the Hungarian predominance of the population is felt in the elections electoral. $37.9 \%$ of the voting population trusts the representative party of the Hungarian community (UDMR). The differences between Satu Mare and Maramureș counties are produced due to the fact that the Hungarian predominance is found only in the first, through direct contact with the Hungarian state, while Maramureș has direct contact with the Ukrainian state. (Figure 5). 


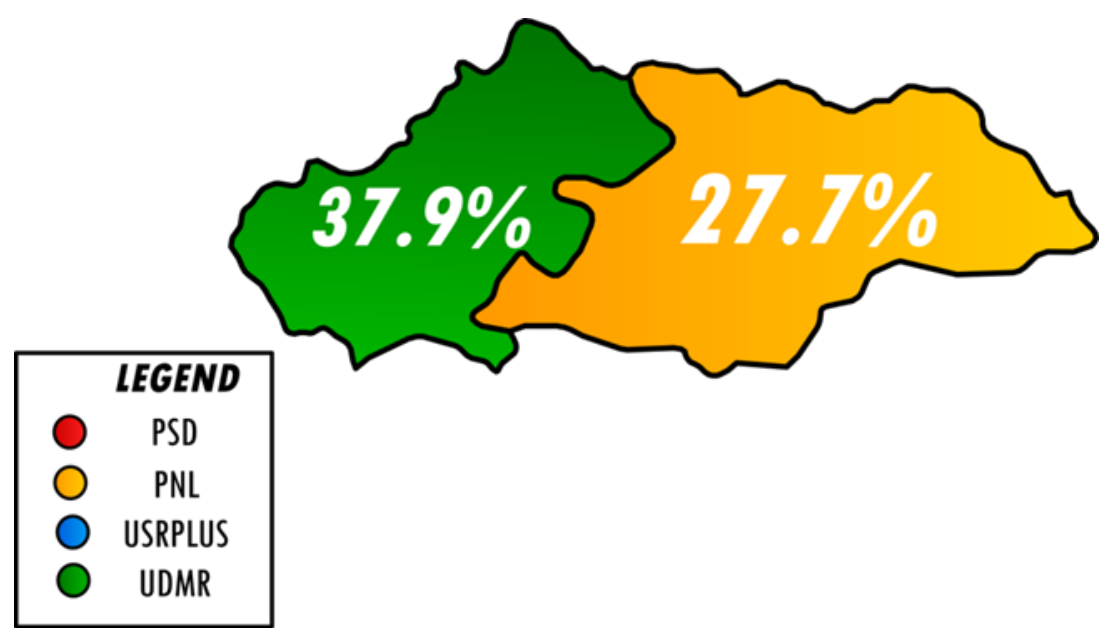

Figure 5. Electoral results of the legislative elections - Maramureș (2020)

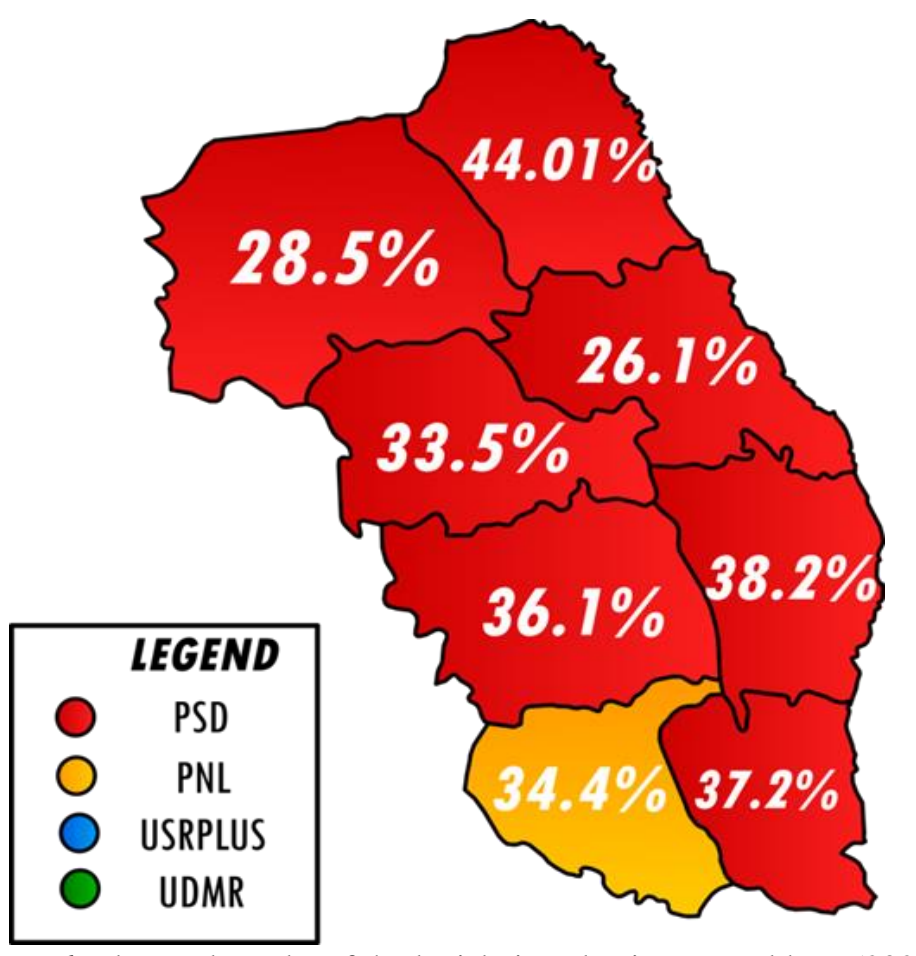

Figure 6. Electoral results of the legislative elections - Moldova (2020)

Moldova presents a resurgence of political ideology in the Social Democratic Party, offering the confidence of seven out of eight counties in the region, with the exception of Vrancea County, which has a dominance of liberal doctrine. The local differences are visible, despite the victory of the counties by the Social Democratic Party, the scores vary between $26-44 \%$, which betrays the presence of a different trust at regional level. Proximity to the USSR (during the communist period) developed a mentality towards socialism, then adapting to the concept of social democracy, further gaining the trust of residents in the region of Moldova (Figure 6).

Muntenia is one of the largest regions of Romania, and through the vast territorial expansion is introduced into discussion the need to section the economy based on existing resources. Despite an almost exclusively agricultural profile, the southern area benefits from its location in the Danube meadow, which facilitates the development of this important economic sector for the entire state, thus offering political potential. From an 
economic point of view, the area also has vast potential for shipyards and the industrial sector, thus providing premises regarding the sectors in which the population operates, the necessary level of education for performance in these sectors, but also the differentiated political mentality. with the western area, in view of the fact that the border continues with a partner communist area. Thus, at territorial level we distinguish a dominance of the social-democratic ideology, through the PSD representative, who manages to obtain eight out of ten counties of Muntenia, with weights of over $32 \%$ for each, except Giurgiu and Ilfov counties, aimed at the liberal profile. The city of Bucharest was won by the representatives of the USRPlus party, a party with a central, pro-European and anti-corruption ideology, thus illustrating the fact that the national administration is not in line with the level expected by the inhabitants of the capital. (Figure 7).

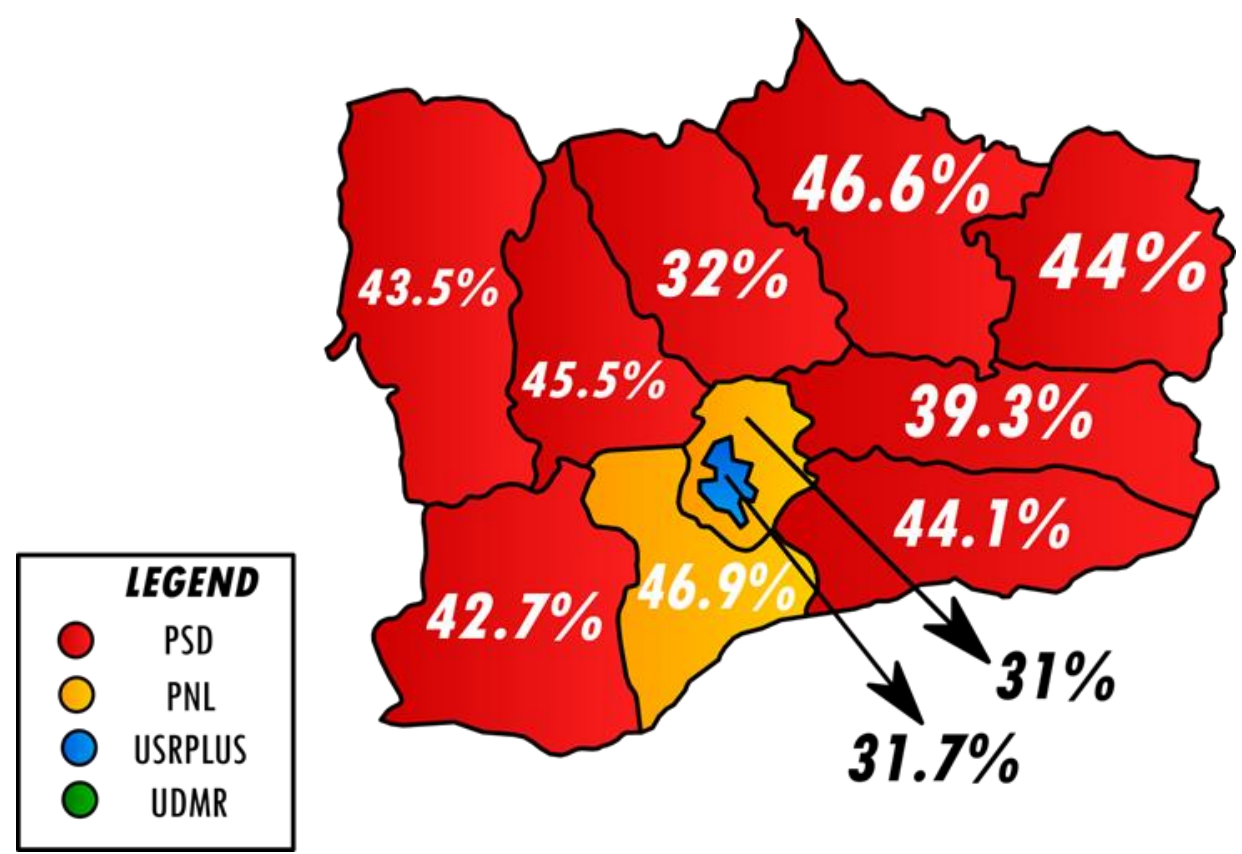

Figure 7. Electoral results of the legislative elections - Muntenia (2020).

Oltenia is the only one of the Romanian regions that presents a predominant ideology for the entire territorial reality, the social democracy thus managing to obtain here an extremely beneficial pole for dissolving the existing political niches, thus providing the necessary to win the political race with right-wing political opponents. Confidence in the social-democratic ideology is extremely visible, with weights of over $39 \%$ for all the analyzed counties, obtaining a maximum score of over $58 \%$ in Olt county (Figure 8).

The confidence of the Oltenia population continues in Transylvania, in a single county, namely Hunedoara county, the Social Democratic Party obtaining the trust of over 39\% of the voting population, unlike the Transylvanian trends, trusting the center and right parties, but and in the parties representative of the Hungarian population. The counties of Mures, Covasna and Harghita are known for a majority dominance of the Hungarian population, proclaiming their area as the Szekler Land, thus offering the minimum necessary for the UDMR party to enter the Romanian Parliament and to be involved in national decisions. USRPlus earns the trust of the people of Brasov, with a share of $27 \%$, a small share compared to the neighboring counties, but sufficient to obtain dominance. The liberal zone of Transylvania is composed of the counties of Salaj, Bistrita, ClujNapoca, Alba and Sibiu, counties in which the National Liberal Party obtains the trust of 
over $27 \%$ of the voting population, reaching the maximum point in Sibiu (41.7\%), through increased trust in the relationship between the president and the National Liberal Party, as the president Klaus Iohannis is the former mayor of Sibiu. (Figure 9)

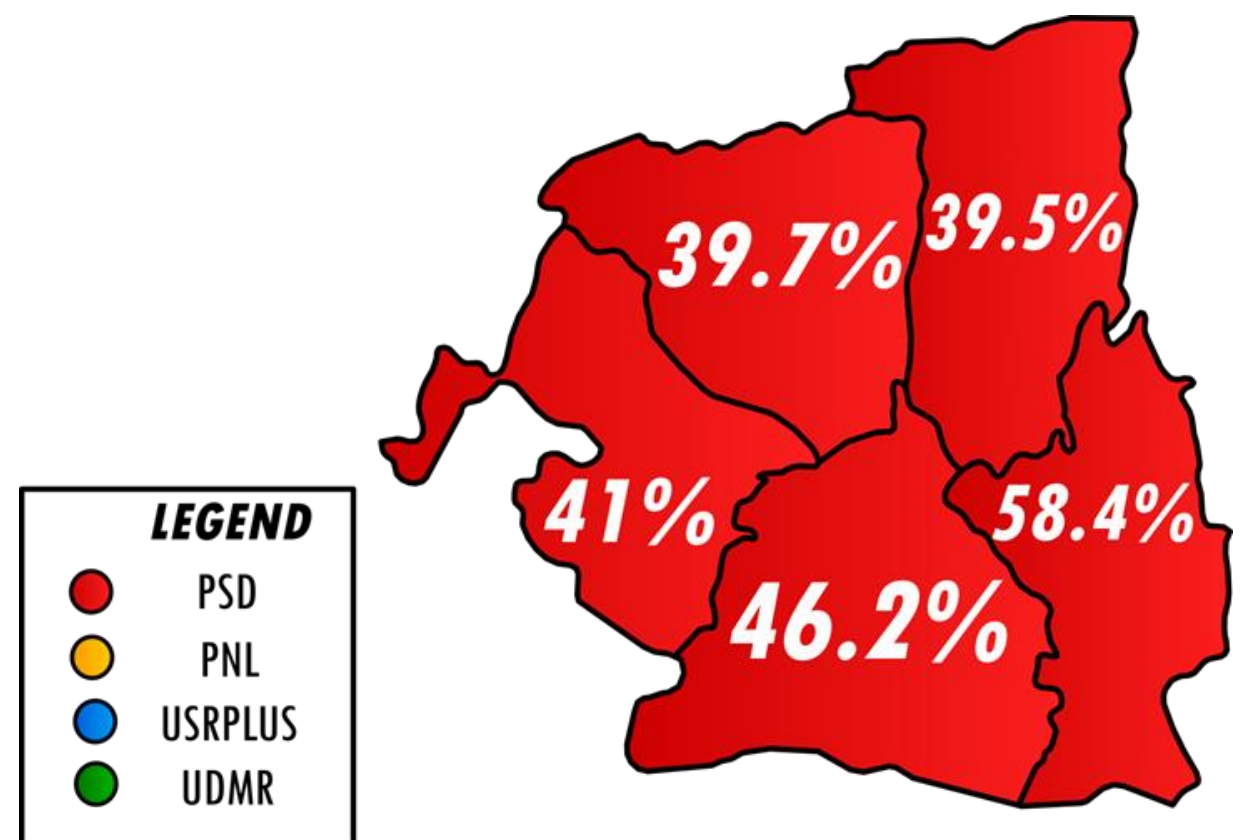

Figure 8. Electoral results of the legislative elections - Oltenia (2020).

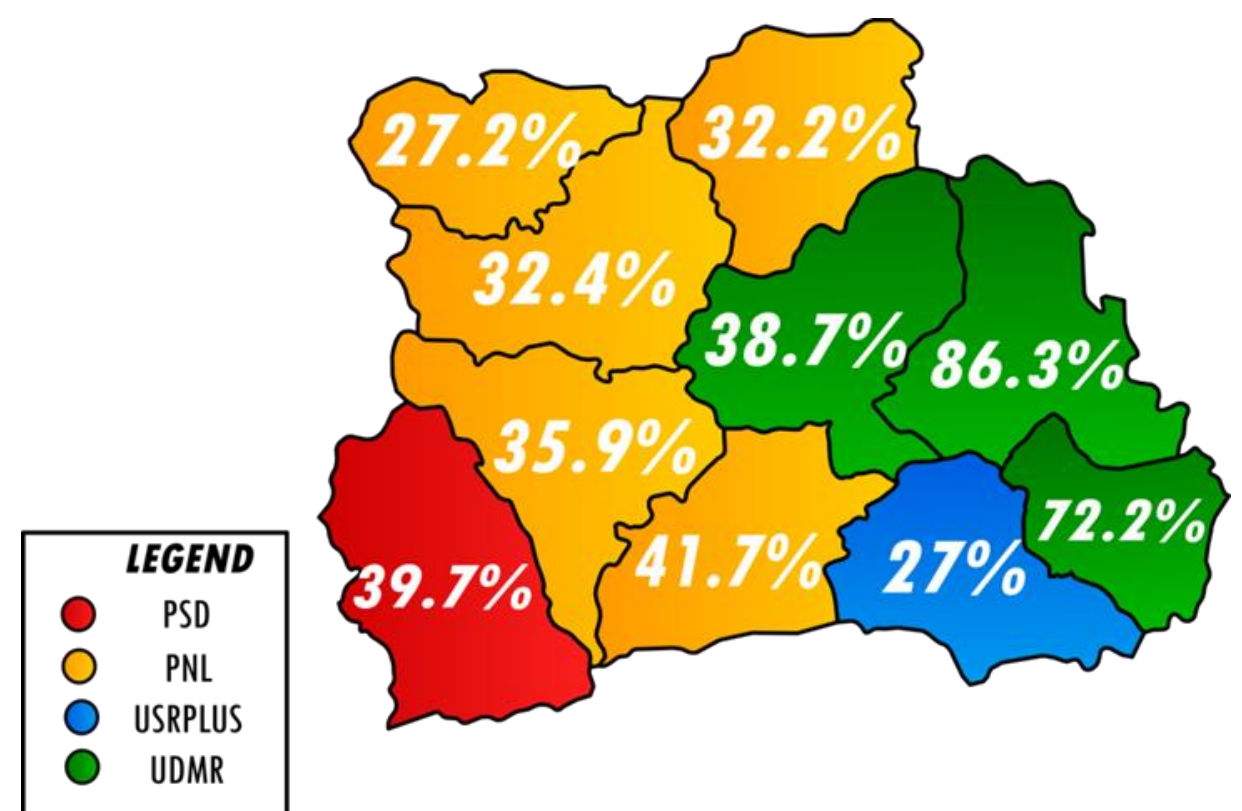

Figure 9. Electoral results of the legislative elections - Transilvania (2020)

\section{CONCLUSIONS}

The research managed to meet the main objectives and to identify the main areas of interest for important political parties, identifying a dominance of liberal doctrine in western Romania, especially in the regions of Banat, Crișana, Maramuress or Transylvania, but also an extremely intense influence. of the Social Democratic Party in Muntenia and Moldova. Also, the secondary objectives were met, by illustrating the 
relevance that the Hungarian communities have on the national political decision, UDMR benefiting from important gains in Satu Mare, Mures, Covasna and Harghita counties, already known for the ancient ethnic mix with the local population.

\section{REFERENCES}

[1] Ezcurra, R., 2020. Individualism and political instability. European Journal of Political Economy, available at: https://doi.org/10.1016/j.ejpoleco.2020.101959

[2] Galindo-Silva, H., 2020. Political openness and armed conflict: Evidence from local councils in Colombia. European Journal of Political Economy, available at: https://doi.org/10.1016/j.ejpoleco.2020.101984.

[3]Petrisor, A.I. et al, 2016. Assessing the fragmentation of the green infrastructure in Romanian cities using fractal models and numerical taxonomy, Ecosmart - Environment at Crossroads: Smart Approaches for a Sustainable Development, Edited by:Ioja, IC; Comanescu, L; Dumitrache, L; Nedelea, A; Nita, MR, Book Series: Procedia Environmental Sciences, Vol. 32, pp. 110-123.

[4] Pintilii R.D. et. al, 2017. Socio-Economic Geography Creative economies in Romania-spatial projections and trends, Bulletin of Geography, Socio-economic Series, Vol. 37, pp. 95-108.

[5]Pintilii, R.D. et al, 2017. Using Fractal Analysis in Modeling the Dynamics of Forest Areas and Economic Impact Assessment: Maramures County, Romania, as a Case Study, Forests, Vol. 8.

[6]Pravalie, $\mathrm{R}$ et al, 2016. Water deficit and corn productivity during the post-socialist period. Case study: Southern Oltenia drylands, Romania, Arid Land Research and Management, Vol. 30, nr. 3, pp. 239-257.

[7] Rădoi I.V. et. al, 2020. The impact of the development of the local economy on the natural environment of the Danube Delta, Romania, Public recreation and landscape protection, pp. 489.

[8] Sears, D.O \& Funk, L.C., 1991. The Role of Self-Interest in Social and Political Attitudes. Advances in Experimental Social Psychology, Vol. 24, pp. 1 - 91.

[9] Teodoresc, C., \& Szemkovics, L.S., 2017. The ethno-creativity in the pilot centers in Romania and their role in the development of cultural tourism and the educational process, Geographical studies and environment protection research vol. 16, nr. 1, pp. 88-97.

[10] Teodorescu C. et. al, 2019. Disfunctionalities in the Organization and Development of SPA Tourism Developed on Salt Resources in Maramureș, Romania, Public Recreation and Landscape Protection, Vol. 1, pp. 101-105.

[11] Teodorescu C. et. al, 2016, Religious and cultural tourism and the socio-economic and educational implications. Quaestus Multidisciplinary Research Journal, Vol. 8, pp. 227- 285.

[12] Teodorescu C. 2009. Turism cultural, Editura Transversal, Targoviste, Romania.

[13] Weinschenk, A.C. et. al., 2021. The relationship between political attitudes and political participation: Evidence from monozygotic twins in the United States, Sweden, Germany, and Denmark. Electoral Studies, Vol. 69. 